\title{
Marine ecosystem engineering by the alien ascidian Pyura praeputialis on a mid-intertidal rocky shore
}

\author{
Juan Carlos Castilla ${ }^{1, *}$, Nelson A. Lagos ${ }^{1,2}$, Mauricio Cerda ${ }^{1}$ \\ ${ }^{1}$ Center For Advanced Studies in Ecology \& Biodiversity (CASEB), Facultad de Ciencias Biológicas, Pontificia Universidad \\ Católica de Chile, Casilla 114-D, Santiago, Chile \\ ${ }^{2}$ Present address: Escuela de Ciencias Básicas, Universidad Santo Tomás, Manuel Rodríguez 97, Santiago, Chile
}

\begin{abstract}
Engineer species transform ecosystems due to their own growth, constitute an integral part of altered environments, and provide new habitats for other species, thus affecting biodiversity and the ecosystem. On rocky shores inside Antofagasta Bay (Northern Chile), the alien ascidian Pyura praeputialis, an engineer species, creates broad belts and dense 3-dimensional matrices that modify the intertidal habitat structure. In all, 116 species of macro-invertebrates and algae inhabit this habitat, compared with the 66 species inhabiting adjacent intertidal rocky shores which lack P. praeputialis. Of the 145 species recorded at the seascape scale (encompassing both mid-intertidal habitat), $55 \%$ were found exclusively in intertidal P. praeputialis matrices. Along the coastal gradient, patterns in $\beta$-diversity emerge due to the addition of a new set of species to the community inhabiting the $P$. praeputialis matrices and, to a lesser extent, from spatial turnover. We found differences in the shape of the species frequency distribution between the communities inhabiting the engineered and non-engineered mid-intertidal habitats. However, within the same habitat type, there was no difference in the species frequency distribution between functional groups. Occurrence of macro-algae was not affected by habitat type, but occurence of macro-invertebrates increased significantly in $P$. praeputialis matrices. P. praeputialis increases species richness at local and seascape scales by providing a novel mid-intertidal habitat which is used by mobile and vagile macro-invertebrates that otherwise would remain excluded from this intertidal level.
\end{abstract}

KEY WORDS: Pyura praeputialis matrices · Ecosystem engineer · Intertidal seascapes $\cdot \alpha-$ and $\beta$-diversity $\cdot$ Species frequency distribution $\cdot$ Northern Chile

\section{INTRODUCTION}

Ecosystem engineer species (Jones et al. 1994, 1997) create, modify and/or increase habitat heterogeneity (e.g. in the sea: corals, macro-algae, mussels, ascidians), and may be part of biological mechanisms maintaining high species richness at local, seascape (Roff et al. 2003), and regional scales (Tokeshi \& Romero 1995, Crooks 1998, Crooks \& Khim 1999, Cerda \& Castilla 2001, Thiel \& Ullrich 2002). According to Jones et al. (1994), the largest effects of engineering may be attributable to species with large per capita impacts, which live in high densities, generate structures that persist for long periods and modulate the distribution and use of resources. However, to predict the effect of an ecosystem engineer species on ecological diversity, it is necessary to under- stand how the species pool responds to these changes (Wright et al. 2002). Several authors have predicted that ecosystem engineers increase species richness by altering habit complexity and providing new habitat (Jones et al. 1994, 1997, Alper 1998, Coleman \& Williams 2002, Reichmann \& Seabloom 2002, Wright et al. 2002).

Engineered habitats have different community compositions compared to non-engineered ones. This can lead to increased species richness at the landscape scale (i.e. involving multiple patch types), when species are present that are restricted to engineered habitats at least during some stages of their life cycle (Wright et al. 2002). Further, engineer species also create resources that are not otherwise available, and species that utilise them are subsequently present (Gutierrez et al. 2003). This suggests that although sites from engineered and 
non-engineered habitats may have similar local or $\alpha$-diversity patterns, $\beta$-diversity, along a geographical gradient (i.e. the spatial turnover in species composition), may show high values when sites from distinctive habitats are compared. However, spatial patterns in $\beta$-diversity may also arise from spatial trends in $\alpha$-diversity (Harrison et al. 1992). Therefore, to understand the increase in species diversity promoted by ecosystem engineers, it is necessary to distinguish between real spatial turnover in species composition between engineered and non-engineered habitats and spatial differentiation between communities which are generated by the addition or loss of species from the regional pool. So far there are no studies addressing changes in marine diversity along geographical gradients with regards to engineering processes. If the consequences of engineering are observed at the landscape (or seascape) scale, with some species present exclusively in the modified habitat and others solely in the non-modified habitat (Wright et al. 2002), then the differences must be also reflected in changes in the species frequency distribution between habitats. Metapopulation models have addressed regional frequency distributions with few common and many rare species (Brown 1984), or a bimodal shape (Hanski 1982). For instance, Collins \& Glenn (1997) demonstrated that such patterns depend on the aerial extent of the study (i.e. distance scaling; see van Rensburg et al. 2000 for changes in species frequency distribution between patch types). This may also apply to patterns in species frequency distribution when comparing engineered and non-engineered habitats (hereafter referred to as habitat scaling). Since there are species that inhabit only non-engineered or engineered habitats (Wright et al. 2002), it is expected that at the landscape scale the species frequency distribution does not present common species (i.e. species occurring in all plots across the landscape). The engineering effect on biodiversity would not necessarily be identical for all species in the landscape pool, where some species would benefit from the new habitat availability, while others would be excluded (Wright et al. 2002). Therefore, spatial patterns in species diversity and frequency distribution may change when applied to different taxa (i.e. organismal scaling, Collins \& Glenn 1997). In the context of ecosystem engineering, the segregation of species into functional groups (e.g. for rocky intertidal habitats: macro-invertebrates, sessile, mobile, macro-algae) may reveal which species set is most affected, in terms of spatial distribution, by the availability of the engineered habitat, and may also provide information regarding the mechanisms by which a engineer species generates an increase in species richness at the landscape scale.

The barrel-shaped ascidian Pyura praeputialis generates extensive aggregations of individuals in the mid- intertidal zone of rocky shores. In Chile, P. praeputialis is considered a recent invader (Castilla et al. 2002) and is exclusively present along approximately 60 to $70 \mathrm{~km}$ of coastline inside Antofagasta Bay. It shows a notable disjoint geographical distribution (Castilla \& Guiñez 2000), with the nearest neighbours present along the southern shores of Australia (Kott 1985, Fairweather 1991, Dalby 1997, Castilla et al. 2002, Monteiro et al. 2002). P. praeputialis aggregations attain 3-dimensional (3D) pseudo-colonality (Paine \& Suchanek 1983, Guiñez \& Castilla 2001) that show wide, almost continuous intertidal belts and high percentage cover (ca. 1800 ind. $\mathrm{m}^{-2}$, Castilla et al. 2000). Cerda \& Castilla (2001) reported that the macro-invertebrate diversity of species (96 taxa) inhabiting the P. praeputialis matrices is one of the highest values reported for the mid-intertidal zone in this geographical area. Nevertheless, the study did not incorporate mid-intertidal macro-algae, which are known to be important components of species diversity in northern Chile (Camus \& Lagos 1996).

The objectives of this paper are to: (1) report on the diversity of macro-algae and macro-invertebrates inhabiting Pyura praeputialis matrices, (2) test whether the novel mid-intertidal habitat provided by this alien ascidian promotes an increase in the species richness at the seascape scale (i.e. encompassing both habitat types: rocky shores with and without $P$. praeputialis matrices), (3) explore $\alpha$ - and $\beta$-diversity patterns to evaluate whether the increase in species richness is due to the addition or spatial turnover of species, (4) test whether species frequency distribution differs between the 2 contrasting mid-intertidal habitats and between functional groups. Thus, our main underlying hypothesis is that matrices of $P$. praeputialis create new midintertidal habitats, otherwise unavailable in the region, which significantly increase species richness at the seascape scale and thereby modify biodiversity and the structure of intertidal communities in northern Chile.

\section{MATERIALS AND METHODS}

The study was performed on 7 sites along approximately $200 \mathrm{~km}$ of coastline (Fig. 1). All study sites were mid-intertidal rocky platforms that received direct wave exposure, had slopes $<20^{\circ}$, and similar substrate heterogeneity (as described in Castilla 1981). Inside Antofagasta Bay we sampled mid-intertidal Pyura praeputialis matrices (i.e. belts of $P$. praeputialis matrix habitats: hereafter $P p \mathrm{MH}$ ) at 3 sites: Curva Lenguado, El Way and El Eden. North and south of the bay we sampled the mid-intertidal rocky habitat at 4 sites where $P$. praeputialis was absent (i.e. P. praeputialisless substrate habitat: hereafter $P p$-LSH): Caleta El Cobre and Jorguillo Point, both to the south of Antofa- 
gasta Bay, and Lagarto Point and La Lobería Point, both to the north of the bay (Fig. 1).

Sampling of $\mathbf{P p M H}$ diversity. The optimum plot size for sampling macro-invertebrates in the Pyura praeputialis matrices was estimated as a $35 \times 35 \mathrm{~cm}\left(0.1225 \mathrm{~m}^{2}\right)$ quadrant, with 4 replicates per site (Cerda \& Castilla 2001). To sample the $P$. praeputialis matrices we used the following procedure: (1) a $35 \times 35 \times 35 \mathrm{~cm}$ iron cube was randomly placed on top of the Pyura matrix, at the height of the mid-intertidal fringe (100\% cover in all cases) approximately $1 \mathrm{~m}$ above the lower intertidal limit of P. praeputialis belt (Castilla 1998, Cerda \& Castilla 2001), (2) the cube was hammered into the Pyura matrix until reaching the underlying rock, (3) individual $P$. praeputialis were carefully removed using iron chisels, (4) all macro-invertebrates and macro-algae (larger than $5 \mathrm{~mm}$ ) found inside the $P$. praeputialis clumps were collected, (5) the removed $P$. praeputialis clumps were stored in plastic bags, transported to the laboratory and kept at $-18^{\circ} \mathrm{C},(6)$ each clump was separated into $P$. praeputialis individuals, and invertebrates and algae found in or on the tunicate where collected, (7) residual material (i.e. sand, gravel, and broken shells) generated during the sorting was separated out using $500 \mu \mathrm{m}$ plastic sieves, and remaining invertebrates were collected. All individuals collected were identified to the lowest taxonomic level (Cerda \& Castilla 2001).

Sampling of $\boldsymbol{P p}$-LSH diversity. We sampled midintertidal communities on rocky platforms, where the condition of rocky shore lack Pyura praeputialis and the mussel Perumytilus purpuratus (which is the dominant intertidal species of central Chile, Broitman et al. 2001). In general, the mid-intertidal zone of northern Chile is dominated by 3 sessile species: the barnacles Jehlius cirratus and Notochthamalus scabrosus and the macro-alga Ulva sp. (Camus \& Lagos 1996). At each study site, we used 6 randomly placed $50 \times 50 \mathrm{~cm}$ $\left(0.25 \mathrm{~m}^{2}\right)$ sample quadrants following this sampling scheme: (1) plots were randomly placed at the midintertidal fringe, approximately $1 \mathrm{~m}$ above the upper limit of the Lessonia nigrescens kelp belt, (2) macroinvertebrates and macro-algae were removed by hand, using knives and iron chisels, and stored, analysed and taxonomically identified as indicated above.

Data analysis. We constructed a database combining our data for macro-algae and macro-invertebrates, for both mid-intertidal habitat types, with data from Cerda \& Castilla (2001) for macro-invertebrates inhabiting the $P p M H$. Data were pooled from the 2 study programs, presenting differences in the number and size of quadrats used; therefore, standardisation by area was carried out (Gotelli \& Colwell 2001). To estimate the degree of overlap in species composition between the 2 habitat types we used non-metric multidimensional scaling ordination (NMS, McCune \& Meffort 1999)

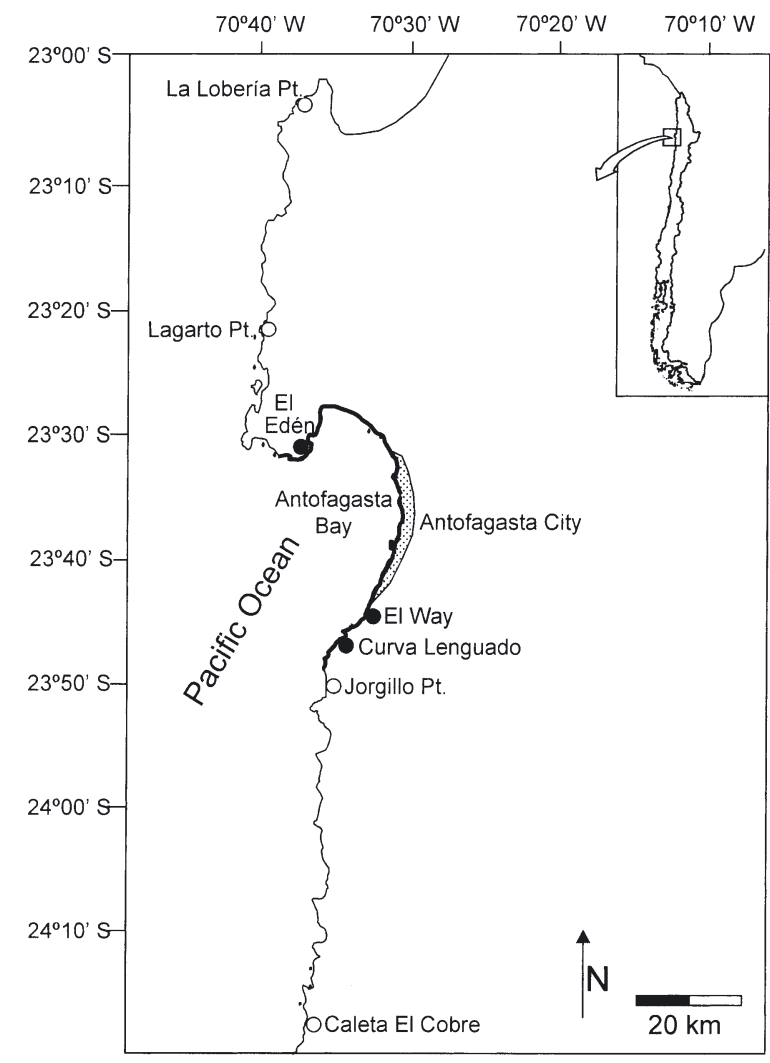

Fig. 1. Study region on the northern Chilean coast. Pyura praeputialis only inhabit the rocky intertidal and shallow subtidal areas (bold line) along the coast of Antofagasta Bay (•: study sites). Adjacent sites are located in areas with extended rocky shores (O: Pyura praeputialis-less substrate habitat $[P p$-LSH] study sites)

based on species presence-absence data at the plot level. We also explored differences in levels of similarity in species composition within and between habitat types, calculating the Morisita-Horn similarity index for all pair-wise comparisons of plots ${ }^{1}$. Testing for differences in species composition was done using 1-way ANOVA with 3 levels of comparison: $P p$-LSH vs $P p$ $\mathrm{LSH}, P p \mathrm{MH}$ vs $P p \mathrm{MH}$, and $P p \mathrm{MH}$ vs $P p$-LSH. The proportional data of similarity indices were square-root transformed to meet ANOVA assumptions (SAS Institute 1996). Species richness in $P p M H$ and $P p$-LSH was estimated by pooling all plots from each habitat type (12 and 24 plots respectively). At the seascape scale, species richness was estimated by pooling data from all plots $(\mathrm{n}=36)$. Estimates of species richness were rarefied to correct for differences in area and sample size, as suggested by Gotelli \& Colwell (2001), by using 100 runs of the Coleman rarefaction estimate ${ }^{1}$. In all cases,

\footnotetext{
${ }^{1}$ Colwell RK (1997) EstimateS: statistical estimation of species richness and shared species from samples, Version 5. Available at www.viceroy.eeb.uconn.edu/estimates
} 
the estimated species richness reached an asymptotic value indicating an adequate sample size. The size of the effect of $P p M H$ on species richness $(\Delta S)$ in the midintertidal zone was assessed by estimating the difference in species richness between both habitat types. This was accomplished by computing the 2 observed distributions for species richness $(S)$, with mean $S_{2}$ for $P p$-LSH and $S_{1}$ for $P p M H$. This was calculated as: $\Delta S=$ $S_{1}-S_{2}$. To avoid non-independence of pair-wise differences between $S_{1}$ and $S_{2}$ we approximated the distribution of $\Delta S$ through simulations in a Bayesian framework (see Albert 1996). Using a uniform non-informative prior distribution, we simulated 5000 random values from each normal distribution using the Coleman estimated species richness and its standard deviation (Colwell 1997). The difference between $S_{2}$ and $S_{1}$ was computed for each pair of simulated values, and the $95 \%$ Student's $t$-test confidence interval for the posterior simulated distribution of $\Delta S$ was estimated. These analyses provided us with an error measure in the estimation (e.g. Wright et al. 2002). We computed $\Delta S$ using the Coleman estimated species richness at the asymptotic value and the estimate corrected for the sampled area (Gotelli \& Colwell 2001, Wright et al. 2002). Given that the $P p \mathrm{MH}$ plots were smaller than the $P p$-LSH plots, we selected a corrected area of $1.4 \mathrm{~m}^{2}$ to compare the estimated species richness between the contrasting habitats (11 plots from $P p \mathrm{MH}$ and 6 plots from $P p$-LSH).

To explore how the presence of mid-intertidal Pyura praeputialis matrices modifies the spatial geographic diversity pattern along the studied rocky shores, we grouped the species into 4 functional groups: macroalgae, sessile macro-invertebrates, mobile macroinvertebrates, and vagile macro-invertebrates. For each functional group, and for the entire set of taxa, we calculated the $\alpha$ - and $\beta$-diversity along the geographical gradient. To examine the spatial turnover in species composition between adjacent sites, we used Whittaker's (1972) measure of $\beta$-diversity, $\beta-1=(S / m)-1$; where $S$ is the combined number of species in the paired, adjacent sites, and $m$ is the average richness for the 2 sites. This measurement ranges from zero (complete similarity) to 1 (complete dissimilarity). However, to distinguish between the true spatial turnover from the spatial trends in the $\alpha$-diversity patterns induced by simple losses or additions of new species, we used the $\beta$-2-diversity index $=\left(S / \alpha_{\max }\right)-1 /(n-1) ;$ where $\alpha_{\max }$ refers to the maximum value of $\alpha$-diversity of all $n$ sites (Harrison et al. (1992). The spatial patterns of $\alpha-, \beta$-1- and $\beta$-2-diversity, calculated for the entire set of taxa, were correlated with the corresponding diversity index, but calculated separately for each functional group. The analysis provided an approximation for which functional groups were more important in the generation of the geographical pattern of differentiation in species composition.
To assess whether the frequency distributions of species inhabiting $P p M H$ was different from those in $P p$ LSH, we calculated the proportion of plots $(P)$ occupied by each species $i$, as $P_{i}=p / n$; where $p$ is the number of plots occupied by the species and $n$ is the total number of plots. The analysis was done at the scale of plots since there was evidence of changes in species diversity at the level of individual Pyura praeputialis (Monteiro et al. 2002) and not at the scale of the sites (Cerda \& Castilla 2001). We explored the effect of habitat scaling (see Collins \& Glenn 1997) by plotting the species frequency distribution of the mid-intertidal community for each habitat type and at the seascape scale. We also explored the effect of organismal scaling (Collins \& Glenn 1997) by plotting the species frequency distribution for 2 functional groups (macro-invertebrates and macro-algae) within the 3 habitat categories. To understand whether $P p M H$, in addition to causing changes in the shape of the species frequency distribution, also promoted an increase or decrease in species occurrence, we estimate the effect of $P p M H$ as the difference, $\Delta P_{i 1}=P_{i P p \mathrm{MH}}-P_{i P p \text {-LSH. }}$. We plotted the frequency distribution of $\Delta P$ to obtain the shape and direction of the effect, using the entire taxa data set, and segregated the data into macro-invertebrate and macro-algae functional groups. Difference in organismal, habitat scaling and in the shape of $\Delta P$ between functional groups was tested using a Kolmogorov-Smirnov 2-sample test, whereas the direction of the effect of $\Delta P$ was tested using a 1-sample Wilcoxon signed-rank test (Sokal \& Rohlf 1991).

\section{RESULTS}

\section{Effects on mid-intertidal species richness}

Community compositions of the mid-intertidal $P p \mathrm{MH}$ and the corresponding rocky mid-intertidal habitat (Pp-LSH) were different (Table 1). Of the

Table 1. Species richness for macro-algae and macro-invertebrates (separated by functional groups) inhabiting the mid-intertidal of the Pyura praeputialis matrix habitats $(P p M H)$, Pyura-less substrate habitat ( $P p$-LSH) and species common to both mid-intertidal habitats (last column) in the rocky shore of the study zone

\begin{tabular}{|lccc|}
\hline Functional group & $P p \mathrm{MH}$ & $P p$-LSH & Common \\
\hline Algae & & & \\
Sessile & 7 & 12 & 13 \\
Invertebrates & & & \\
Mobile & 56 & 9 & 17 \\
Sessile & 9 & 7 & 7 \\
Vagile & 7 & 1 & 0 \\
Total & 79 & 29 & 37 \\
\hline
\end{tabular}



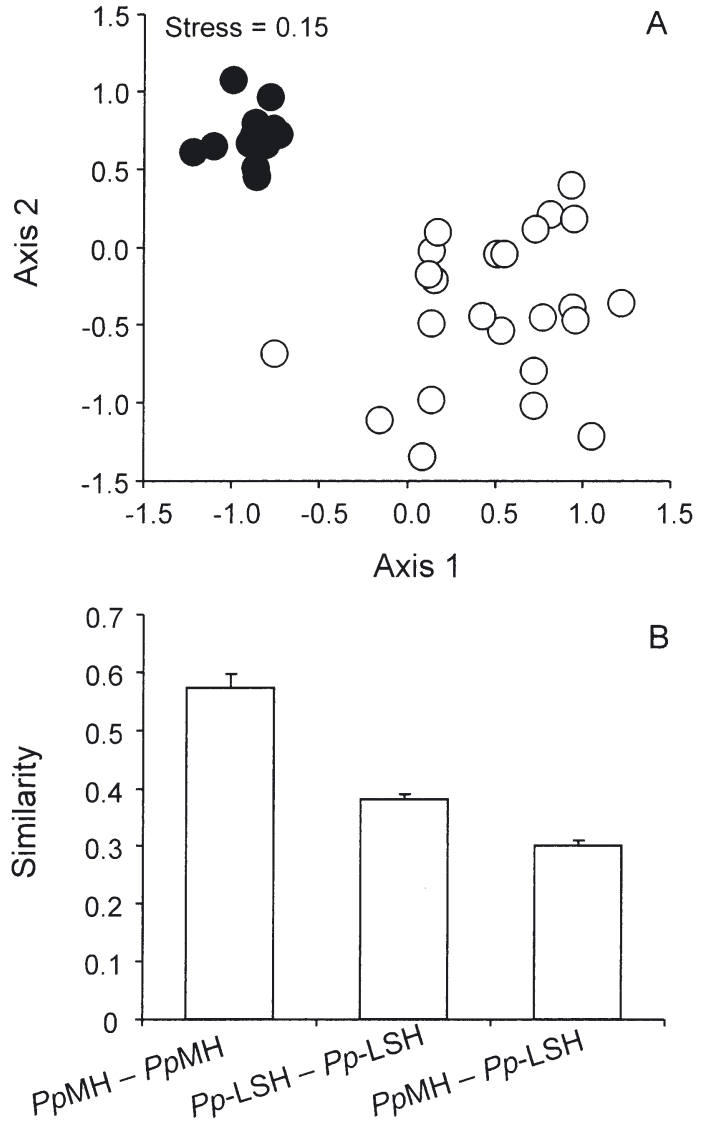

Fig. 2. (A) Ordination of community composition between intertidal habitats. Ordination of plots based on species presence using non-metric multi-dimensional scaling. Pyura praeputialis matrix habitats $(P p M H) ;$ O: rocky platforms or $P$. praeputialis-less substrate habitat ( $P p$-LSH). (B) Similarity (mean $\pm 1 \mathrm{SE}$ of Morisita-Horn similarity index for pairwise comparison) of community composition within ( $P p M H$ or $P p$-LSH) and between $(P p M H$ and $P p$-LSH) mid-intertidal habitat types

79 species recorded exclusively in the $P p M H, 91 \%$ corresponded to macro-invertebrates and $9 \%$ to macroalgae species. In the Pp-LSH there was a total of 29 intertidal species, of which $59 \%$ were macro-invertebrates and $41 \%$ macro-algae species. Thirty-seven species were common to both mid-intertidal habitats (Table 1). The difference in community composition was evident using NMS, which showed a strong segregation between PpMH and Pp-LSH plots (Fig. 2A). Furthermore, there was a significant difference in the similarity of plots within and between habitat types (ANOVA, $F_{2,969}=72.76, \mathrm{p}=0.0001$ ) (Fig. 2B). A comparison of the community composition within $\mathrm{PpMH}$ was highly similar, in contrast to the comparison within $P p$-LSH plots. The between-habitat comparison, $P p \mathrm{MH}$ vs $P p$-LSH, showed a lower level of similarity (Fig. 2B).
Differences in species composition translated into differences in species richness (Fig. 3A). Asymptotic Coleman species richness estimates (mean $\pm 1 \mathrm{SD}$ ) for each habitat type were: $65.5 \pm 0.68$ for $P p$-LSH, and $116.4 \pm 1.2$ for $P p M H$ (Fig. 3A). At the seascape scale, the species richness estimated by random sampling of plots from both habitat types was higher than that estimated for each habitat individually $(S=144.5 \pm 0.69)$. At the asymptote of the Coleman estimate, the effect size of the $P p M H$ on species richness with respect to richness in the $P p$-LSH, was positive and significant, with $\Delta S=50.91$ species $\pm 0.042 \mathrm{SD}$ (Student's $t$-test, $\mathrm{p}<$ 0.0001) (Fig. 3B). Nevertheless, the Coleman estimates corrected for area showed that the difference in species richness in both habitat types rose to $\Delta S=62.8$ spe-
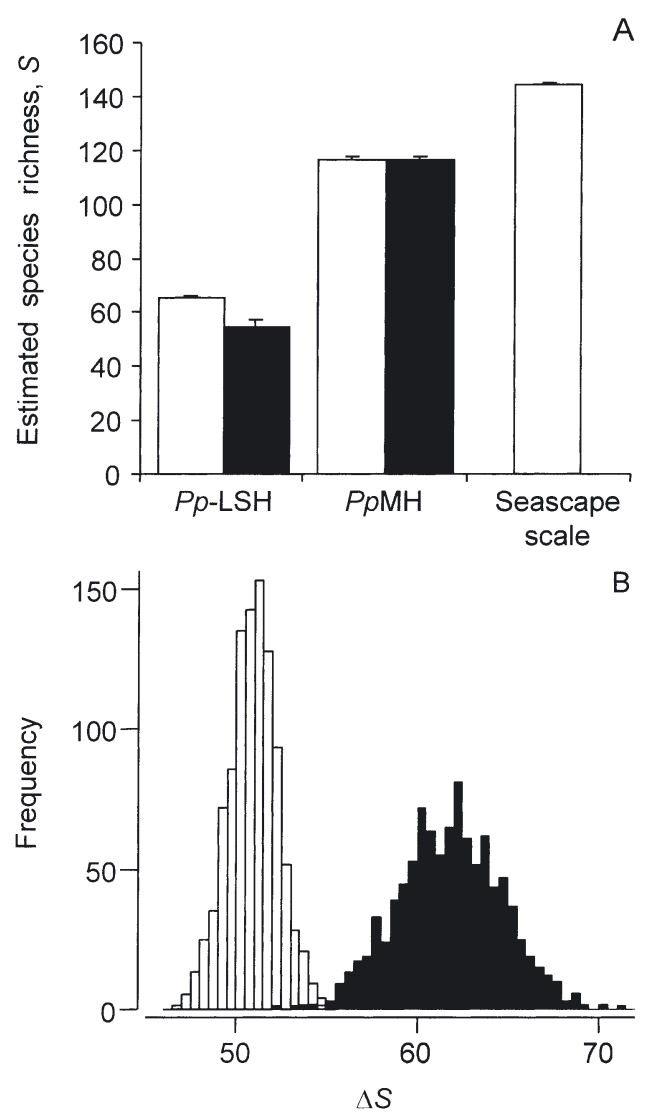

Fig. 3. Pyura praeputialis. (A) Asymptotic estimated species richness $\left(S_{;} \pm 1 \mathrm{SD}\right)$ of hypothetical intertidal seascapes composed only by rock substrata $(P$. praeputialis-less substrate habitat, $P p$-LSH), only by $P$. praeputialis matrix habitats $(P p M H)$, and the combination of both habitats types (seascape scale). Black bars represent the Coleman rarefaction estimate of species richness in an equal sized area of $1.4 \mathrm{~m}^{2}$ in both habitat types. (B) Histogram for simulated values of $\Delta S$, the averaged effect size of $P$. praeputialis on mid-intertidal species richness. $\Delta S$ was calculated as the difference between both habitat types in the Coleman estimate of species richness at the asymptotic value (white bars) and corrected for an equal sized area (black bars) 
cies $\pm 0.092 \mathrm{SD}$ (Student's $t$-test, $\mathrm{p}<0.0001)$ (Fig. 3B). These patterns caused increased richness at the seascape scale, which exhibited 28.06 species \pm 0.04 SD more than the richness estimated in the $P p M H$. Of the 145 species recorded at the seascape scale, 55\% were found exclusively in PpMH plots, whereas $25 \%$ of the species shared both habitat types, and only $20 \%$ were found exclusively in $\mathrm{Pp}$-LSH (Table 1).

\section{Effects on spatial turnover in species composition}

The geographical patterns along the studied rocky shores showed that for the entire taxa set, $\alpha$-diversity increased in the sites with $P p M H$ and decreased in $P p$-LSH sites (Fig. 4A). In addition, high differences in community composition, or $\beta$-1-diversity, were found in the pair-wise comparison between different habitat types (Fig. 4A). These spatial patterns, for total mid-intertidal species, corresponded well with those of $\alpha$ - and $\beta$-1-diversity for total macro-invertebrate species (Fig.4B), but less so with the spatial pattern for total macro-algae (Fig. 4C, see Table 2 for $r$-Pearson correlation and p-values). In general, the relationship of $\alpha$ - and $\beta$-1-diversity patterns among the entire taxa set and the functional groups was positive and significant for all invertebrates and mobile invertebrates (Fig. 4A,D, Table 2). However, the $\beta$-2 estimate did not translate into high values of community differentiation for the pair-wise comparison between different habitat types ( $\times$ in Fig. 4). In addition, the relationship of $\beta$-2-diversity patterns among the entire taxa set and the functional groups was non-significant in all cases (Table 2). Along-shore spatial patterns in $\beta$-1 support that differences in community composition between habitat is influenced by invertebrates (in general) and mobile invertebrates (in particular), after removing the spatial trends in $\alpha$-diversity (i.e. the increase in richness in $P p M H$ sites); the $\beta$-2 estimates do not show a clear spatial turnover. Thus, spatial differentiation among habitat types emerge from the addition of species, mainly mobile invertebrates and, to a lesser extent, to spatial turnover in species composition.
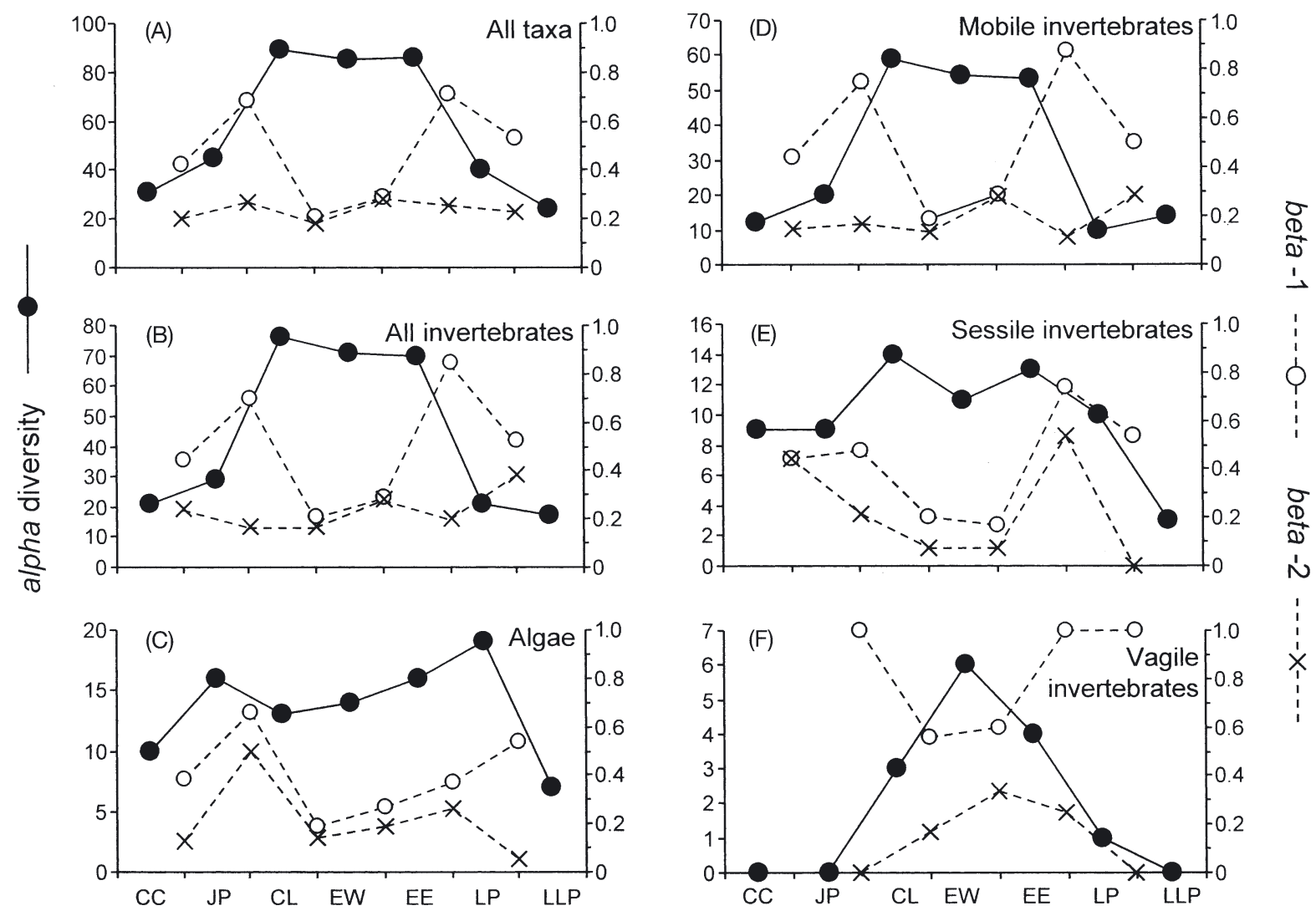

Study sites

Fig. 4. $\alpha$-, $\beta$-1- and $\beta$-2-diversity patterns for (A) the all taxa set and (B-F) functional groups across the geographical gradient. $\beta$ measures were calculated between pairwise adjacent sites. Sites are aligned from south to north (see Fig. 1). Abreviations: CC = Caleta El Cobre, Jp = Jorgillo Point, CL = Curva Lenguado, EW = El Way, EE = El Eden, LP = Lagarto Point, LLP = La Loberia Point 
Table 2. Correlation in $\alpha-, \beta$-1- and $\beta$-2-diversity among all taxa (see Fig. 4A) with the corresponding measure for each functional group (Fig. 4B-F). Correlation based on $\mathrm{n}=7$ sites for $\alpha$-diversity and $n=6$ pairwise comparison of adjacent sites for $\beta$-indices. Significance was evaluated using a Bonferroni correction: ${ }^{* * *} \mathrm{p}<0.001 ;{ }^{* *} \mathrm{p}<0.01$; ns: correlation was not significant

\begin{tabular}{|lccc|}
\hline Functional group & $\begin{array}{c}\alpha \\
r \text {-Pearson }\end{array}$ & $\begin{array}{c}\beta-1 \\
r \text {-Pearson }\end{array}$ & $\begin{array}{c}\beta-2 \\
\text {-Pearson }\end{array}$ \\
\hline Invertebrates & $0.99^{* * *}$ & $0.98^{* * *}$ & $0.06 \mathrm{~ns}$ \\
Algae & $0.35 \mathrm{~ns}$ & $0.77 \mathrm{~ns}$ & $0.59 \mathrm{~ns}$ \\
All taxa with: & & & \\
mobile invertebrates & $0.98^{* * *}$ & $0.98^{* * *}$ & $0.34 \mathrm{~ns}$ \\
sessile invertebrates & $0.84 \mathrm{~ns}$ & $0.90 \mathrm{~ns}$ & $0.06 \mathrm{~ns}$ \\
vagile invertebrates & $0.89^{* *}$ & $0.60 \mathrm{~ns}$ & $0.37 \mathrm{~ns}$ \\
\hline
\end{tabular}

\section{Effects on species frequency distribution}

At the seascape scale, the species frequency distribution showed an inverse relationship between the pro- portion of plots occupied and the number of species, with a mode (48 species) at a the lower proportion and, as predicted, a total absence of species at the highest proportion of plot occupied (zero species with a proportion of plot occupied of 1, Fig. 5A). When species frequency distributions were separated by habitat type (habitat scaling), the distribution in $P p M H$ appeared to be multi-modal, with 3 modes, at low, mid- and high occurrence (18, 15 and 20 spp. respectively) (Fig. 5B). For species inhabiting $P p$-LSH, the species frequency distribution also showed an inverse relationship, with modes at low and intermediate proportions of plot occupied (Fig. 5C). Significant statistical differences in species frequency distribution $(p<0.05)$ emerged when comparisons were done among habitat types (i.e. habitat scaling), but non-significant differences were founded in frequency distribution among functional groups within the same habitat type (i.e. organismal scaling, $\mathrm{p}>0.05$ ) (see Fig. 5). In the PpMH a total of 109 species exhibited an increasing, and 36 a decreasing, trend in the plot occurrence $\Delta P$ (Fig. 6A). This dis-

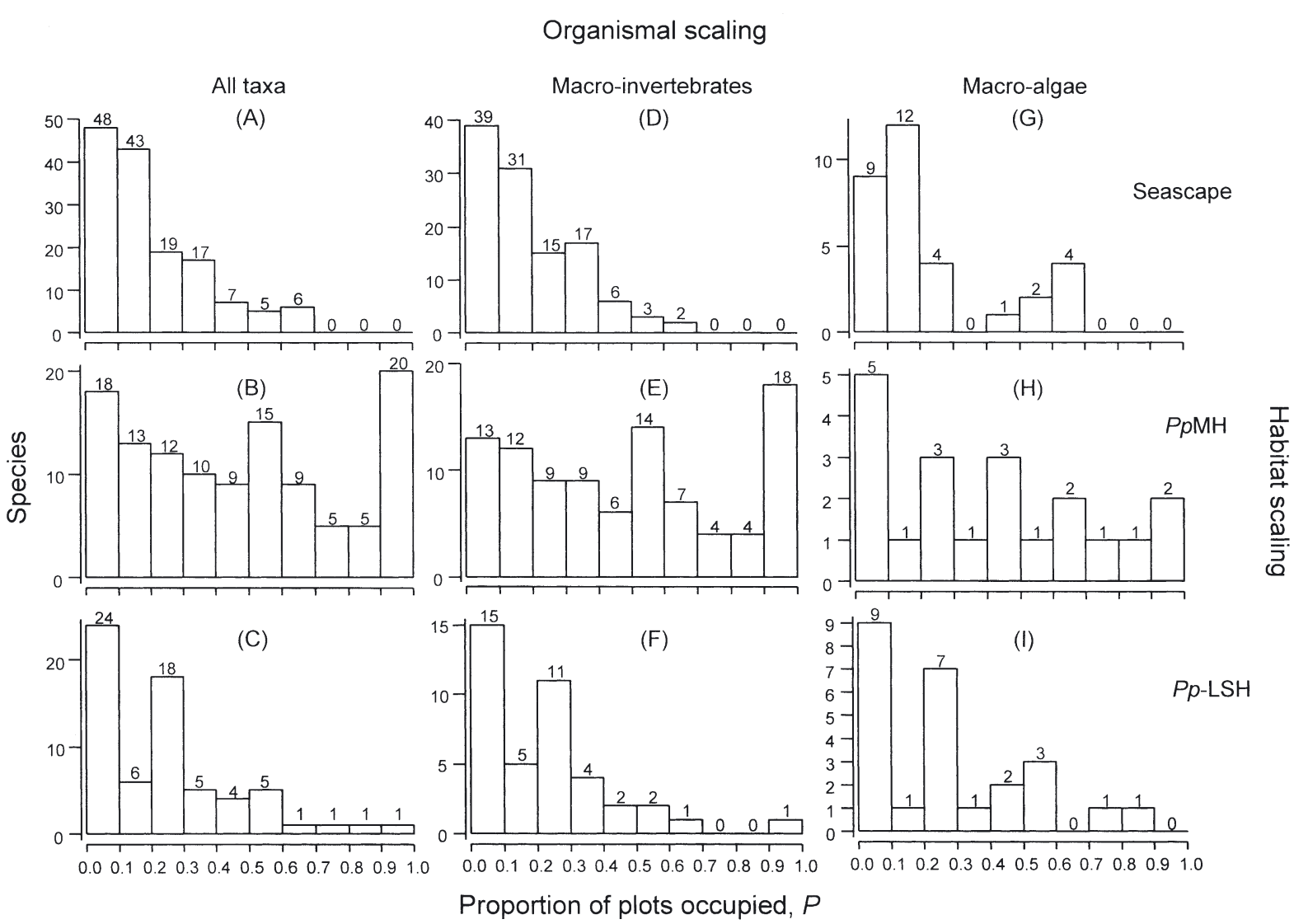

Fig. 5. Effects of habitat type $(P p \mathrm{MH}=$ Pyura praeputialis matrix habitats; $P p$-LSH $=$ P. praeputialis-less substrate habitat, or rocky platforms; seascape scale = pooled habitats) and functional group (algae, invertebrates and all taxa set) on species frequency distribution. Numbers above each bar indicate the number of species. Habitat scaling corresponds to comparison of species frequency distribution the vertical axis (Kolmogorov-Smirnov test, $\mathrm{p}<0.05$ in all cases). Organismal scaling corresponds to comparison on the horizontal axis (Kolmogorov-Smirnov test, $\mathrm{p}>0.05$ in all cases) 
tribution of $\Delta P$ was positive, with a median $\Delta P=0.271$ (Wilcoxon signed-rank test, $\mathrm{p}<0.0001$ ). A similar pattern was found for the macro-invertebrate functional groups (Fig. 6B; $\Delta P$ median $=0.333, p<0.0001$ ) Here, 94 species increased their plot occurrence in $P p M H$, and 19 species decreased in occurrence. However, for the macro-algal species (Fig. 6C), the opposite pattern was observed: median $\Delta P=-0.062$ (Wilcoxon signed-rank test, $\mathrm{p}<0.427$ ). The frequency distribution
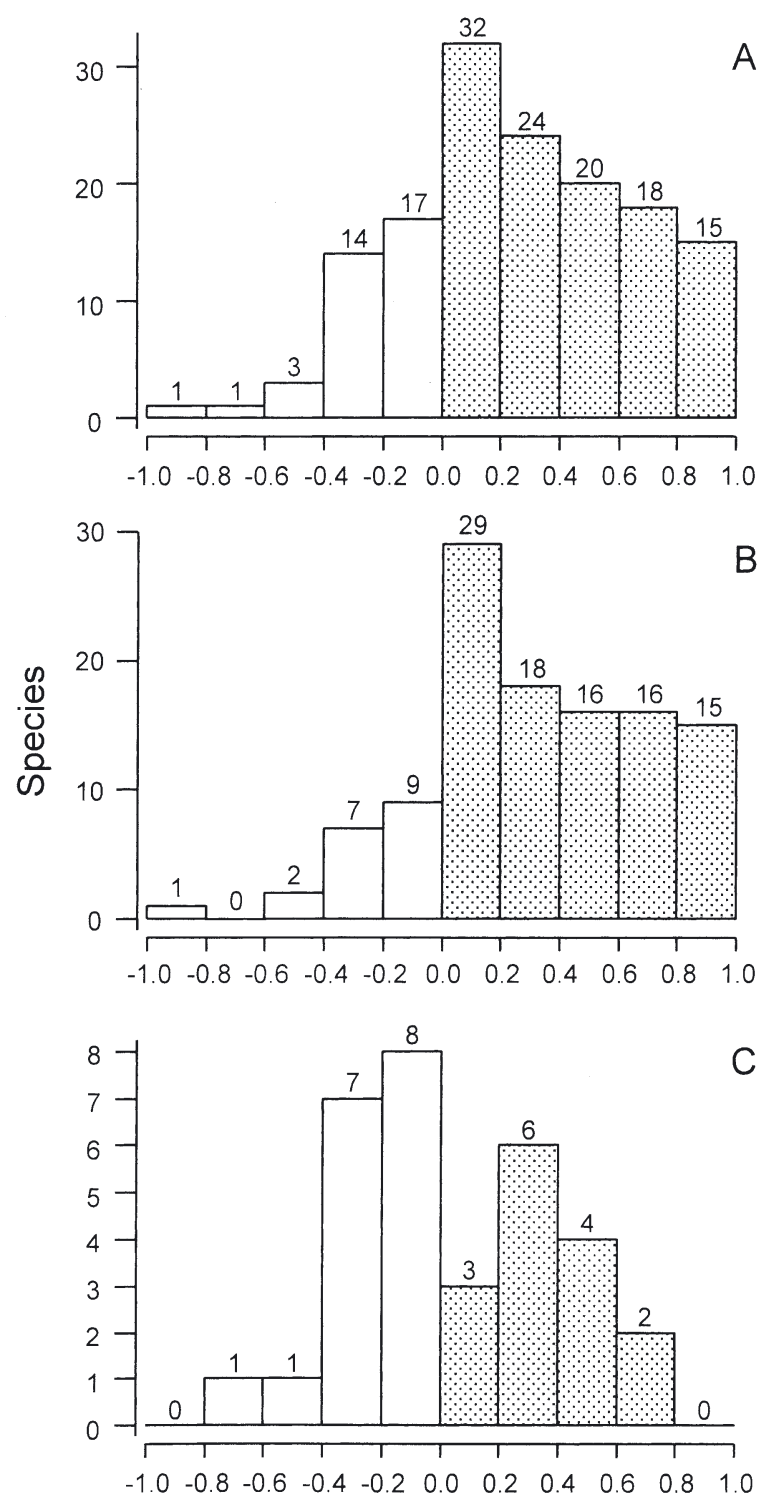

$\Delta P$

Fig. 6. Effect of Pyura praeputialis matrices on the proportion of plots occupied by intertidal species, $\Delta P$, including (A) all taxa and separating for (B) macro-invertebrates and (C) macro-algae functional groups. Stippled bars: positive effect; white bars: negative effect of $\Delta P$ for macro-algae was significantly different from that of macro-invertebrates and for all taxa combined (Kolmogorov-Smirnov 2-sample test, $\mathrm{p}<0.01$ ).

\section{DISCUSSION}

Exposed intertidal rocky shores are species-rich environments, showing zonation patterns, and containing numerous invertebrate and algal taxa, where primary substrate is usually scarce (Castilla 1981, Paine \& Levin 1981). In many cases, the maintenance of species diversity in these habitats has been considered the result of biotic and abiotic mechanisms, operating mainly on dominant competitors for primary substrate (Connell 1961, Paine 1966, Dayton 1971). Nevertheless, as far as species diversity goes, less importance has been given to species that generate secondary substrates (i.e. allogenic engineers, Jones et al. 1994; but see Suchanek 1986, Lohse 1993, Seed 1996, Crooks 2002, Gutierrez et al. 2003), and thereby add to habitat complexity. In this vein, the 60 to $70 \mathrm{~km}$ of modified mid-intertidal rocky shore inside Antofagasta Bay, Chile, represents a unique ecological situation, due to the prevalence of extensive matrices of the dominant tunicate Pyura praeputialis (Castilla 1998, Castilla et al. 2000, Guiñez \& Castilla 2001). This alien ecosystem engineer, has recently (i.e. during the last century/ies?) invaded the Bay of Antofagasta (Castilla et al. 2002), and harbors at least 96 species of macro-invertebrates (Cerda \& Castilla 2001) and 20 species of macro-algae (this paper). Cerda \& Castilla (2001) reported that these species utilize the interstices, cavities and secondary substratum of the $P$. praeputialis matrices (also see Monteiro et al. 2002). Nevertheless, this set of species is also present in the regional pool, but restricted to lower intertidal environments (under boulders, in cavities, crevices, inside holdfasts of macroalgae (Vásquez \& Santelices 1984), or in the subtidal zone. Thus, the large increase in species richness in matrices of $P$. praeputialis results from the creation of novel habitats in the mid-intertidal zone, and to the presence of a large number of species able to exploit the new habitat resource. This allows for an extension of the species vertical distribution and biodiversification of the mid-intertidal at the seascape scale.

The results demonstrate the important increase in the mid-intertidal rocky shore species richness at sites with Pyura praeputialis matrices (total richness $=116$ species), in contrast to sites where $P$. praeputialis was naturally absent (total richness $=66$ species) (see Table 1). Thus, at the seascape scale, encompassing both mid-intertidal habitat types, the richness was 145 species (Table 1). Monteiro et al. 
(2002) reported 64 taxa inhabiting mid-intertidal $P$. stolonifera (= $P$. praeputialis) clumped matrices in Australia, whereas on individual $P$. stolonifera 84 taxa were found. These differences, with respect to our findings, may correspond to geographically specific historical and evolutionary processes affecting intertidal biota differently in Australia and Chile (Paine \& Suchanek 1983, Castilla \& Guiñez 2000, Castilla et al. 2002). The results also suggest the significance (and generality) of the $P$. praeputialis matrices enhancing intertidal species richness (but see Monteiro et al. 2002). For instance, the trends in increased species richness in the engineered midintertidal habitat at Antofagasta corresponds well with the effect of landscape modifications caused by the allogenic engineer, the beaver Castor canadiense, in riparian ecosystems (Wright et al. 2002). However, for C. canadiense, researchers have attributed the observed increase in vascular plant diversity, in engineered habitats, to the increase in beaver disturbance regime, through the elimination of competitively dominant plants (see Hacker \& Gaines 1997 for positive interactions in plant communities; Coleman \& Williams 2002 for marine systems).

Our study demonstrated that matrices of Pyura praeputialis showed an increase in species richness at the local scale ( $\alpha$-diversity, Fig. 4). Therefore, the increase in species richness at the seascape scale does not only imply a spatial turnover in species composition between habitat types, but also reflects a significant addition of new species to the mid-intertidal rocky community that otherwise would remain excluded from this intertidal level. Cerda \& Castilla (2001) reported that macro-invertebrate diversity did not show differences between sites inside Antofagasta Bay, suggesting that the effect of $P$. praeputialis matrices on the increase of species richness was similar along the coast of the bay. This conclusion is supported by the NMS ordination analysis (Fig. 2), where we found high similarity and increased aggregation of species inhabiting $P$. praeputialis matrices. The results show that several species may be excluded from the mid-intertidal seascape level in the absence of the $P p \mathrm{MH}$. Wright et al. (2002) reached a similar conclusion regarding the allogenic engineer Castor canadiense.

The species frequency distribution changed between habitats types, thereby suggesting that Pyura praeputialis matrices play an important role in the underlying processes determining the species abundance of mid-intertidal seascapes. The results also suggest that models describing species frequency distributions (e.g. Hanski 1982, Brown 1984) do not apply to all habitats, particularly not to engineered ones. In general, the importance of habitat scaling in species frequency distributions has not been included in the context of regional or landscape patterns of diversity induced by ecosystem engineers. Nevertheless, this has been suggested as an important factor that complicates the fitting of empirical patterns to the species distributions predicted by some models (Collins \& Glenn 1997). Our results suggest that habitat scaling has a strong effect on the pattern of distribution of rocky shore mid-intertidal species in northern Chile. Monteiro et al. (2002) reported that assemblages associated with Pyura stolonifera in Australia can also be segregated according to habitat type (clumped matrices versus sparse individuals), adding to the generality of changes in species distribution with respect to habitat scaling in the $P$. praeputialis matrices. Numerous studies have shown that different intertidal bio-habitats are associated with different community structures (e.g. Suchanek 1986, Lohse 1993, Tokeshi \& Romero 1995, Thompson et al. 1996, Crooks 1998, 2002, Crooks \& Khim 1999, Thiel \& Ulrich 2002, Wright et al. 2002, Gutierrez et al. 2003). One of the main distinctive patterns reported in our study is the unimodal distribution of species, showing a lack of common species at the seascape scale (Fig. 5A). This distribution has been proposed by Brown (1984) to address patterns of species abundance at very large geographic areas $\left(>10^{3} \mathrm{~km}\right.$, Collins \& Glenn 1991). So far, the pattern may be considered a direct result from differences in community composition between habitat types, or the fact that engineered habitats are inhabited by species excluded from other habitats (Wright et al. 2002). Further, this result may also indicate the ineffectiveness of the sampling techniques for the studied community (Collins \& Glenn 1997).

In spite of the fact that in the $P p M H$ macroinvertebrates showed higher values for occurrence than macro-algae (Fig. 6), in the analysis of these rocky shore mid-intertidal communities, organismal scaling did not emerge (Fig. 5). This suggests that the patterns in abundance and occurrence of different functional groups respond in a similar way to the habitat effect. Collins \& Glenn (1997) suggested that animals might perceive their environments as heterogeneous or homogeneous based on the relationship of dispersal and body size to their environment. In our case, differences in life history traits of the main functional groups did not translate into different patterns of species distribution. This similitude, in spite of differences in composition and richness, suggests a re-organization of the rocky shore mid-intertidal community in both habitat types (Marquet et al. 1990).

The $\alpha$ - and $\beta$-diversity patterns found for this set of intertidal species suggests that the addition of species has a larger role in determining species composition than spatial turnover. The barnacle Notochthamalus 
scabrosus, one of the dominant species of the midintertidal rocky shores (Camus \& Lagos 1996), become excluded inside the $P$. praeputialis matrices, while Jehlius cirratus and Ulva spp. occur at low densities (Cerda \& Castilla 2001). This suggests that sessile species, irrespective of their functional group may be negatively affected by the dominance of $P$. praeputialis. However, when comparing between habitat types, the macroalgae and sessile invertebrate groups had a similar number of species in each habitat type, whereas a high number of mobile and vagile invertebrate species inhabit almost exclusively the $P p M H$ (see Table 1). These results suggest that the sessile species may be more important in determining the spatial differentiation of the mid-intertidal communities between contrasting habitat types, while mobile and vagile macro-invertebrates may be responsible for the increase in species richness inside the $P$. praeputialis matrices.

The macro-invertebrate species reported for midintertidal matrices of Pyura praeputialis in Antofagasta, tend to be restricted to lower intertidal levels in sites where this tunicate is not present, and show cryptic behaviour (Castilla 1981, Vásquez \& Santelices, 1984, Monteiro et al. 2002). Therefore, their presence in the mid-intertidal rocky shore habitats inside Antofagasta Bay necessarily requires the presence of P. praeputialis matrices. This suggests that the recent invasion of the alien $P$. praeputialis into Antofagasta Bay (Castilla et al. 2002) has modified, at both the local and seascape scales, mid-intertidal species richness. These results are consistent with studies suggesting that alien ecosystem engineer species which increase habitat heterogeneity also modify the distribution of the resident biota, and increase species richness (e.g. Musculista senhousia, see Crooks 1998, 2002, Crooks \& Khim 1999). However, our conclusions are restricted to the intertidal horizontal line studied, because species added to the Pyura habitat stemmed from nearby deeper habitats (Cerda \& Castilla 2001). This implies that the expansion of subtidal species into the intertidal may be accompanied by a vertical decrease in $\beta$-diversity.

It has been suggested that Pyura praeputialis is an ecosystem engineer presenting diverse ecological characteristics that effect macro-invertebrates. These include: (1) interference, by providing nursery areas for juveniles which offer protection against predation (for gastropods and decapods, including species which are exploited by intertidal food-gathers; Varas 1996, Fairweather 1991), (2) increasing the chance of survival, by reducing the risk of desiccation for species without external protection (i.e. Polychaeta, Nemertea; Cerda \& Castilla 2001), (3) positive interactions among species, since more diverse communi- ties may have enhanced ecosystem functions (Chapin et al. 1998, Stachowicz 2001), (4) coexistence mediated by spatial and temporal variation in recruitment (Chesson 1986), given that the disturbance regime and patch dynamics of $P$. praeputialis in Antofagasta may promote the coexistence of fugitive species, both inside and on top of the ascidian matrices (Alvarado et al. 2001, Monteiro et al. 2002). Future experimental work should address such issues to understand how the species diversity patterns described here and the role of the $P$. praeputialis matrices are linked by the mechanisms above.

Acknowledgements. We acknowledge financial support from Minera Escondida Ltda. This research was also funded by grant FONDAP-FONDECYT 1501-0001 to the Center for Advanced Studies in Ecology \& Biodiversity. We sincerely acknowledge Paula Neill, Valeria Muñoz and Luis Prado.

\section{LITERATURE CITED}

Albert JH (1996) Bayesian computation using Minitab. Wadsworth Publishing Company, Belmont, CA

Alper J (1998) Ecosystem 'engineers' shape habitats for other species. Science 280:1195-1196

Alvarado JL, Pinto R, Marquet P (2001) Patch recolonization by the tunicate Pyura praeputialis in the rocky intertidal at the bay of Antofagasta, Chile: evidence for a selffacilitation mechanism. Mar Ecol Prog Ser 224:93-101

Broitman B, Navarrete S, Smith F, Gaines S (2001) Geographic variation in southern Pacific intertidal communities. Mar Ecol Prog Ser 224:21-34

Brown J (1984) On the relationship between abundance and distribution of species. Am Nat 124:255-279

Camus P, Lagos NA (1996) Variabilidad espacial y temporal del reclutamiento de ensambles de especies intermareales sésiles del norte de Chile. Rev Chil Hist Nat 69:193-204

Castilla JC (1981) Perspectivas de investigación en estructura y dinámica de comunidades intermareales rocosas de Chile central. II. Depredadores de alto nivel trófico. Medio Ambiente 1:190-215

Castilla JC (1998) Las comunidades intermareales de la bahía San Jorge: estudios de Línea base y el programa ambiental de Minera Escondida Ltda. en Punta Coloso. In: Arcos D (ed) Minería del Cobre, ecología y ambiente costero. Editora Aníbal Pinto, Concepción, p 221-224

Castilla JC, Guiñez R (2000) Disjoint geographical distribution of intertidal and nearshore benthic invertebrates in the southern hemisphere. Rev Chil Hist Nat 73:585-603

Castilla JC, Guiñez R, Alvarado JL, Pacheco C, Varas M (2000) Distribution, population structure, population biomass and morphological characteristics of the tunicate Pyura stolonifera in the Bay of Antofagasta, Chile. Mar Ecol 21:161-174

Castilla JC, Collins AG, Meyer CP, Guiñez R, Lindberg DR (2002) Recent introduction of the dominant tunicate, Pyura praeputialis (Urochordata, Pyuridae) to Antofagasta, Chile. Mol Ecol 11:1579-1584

Cerda M, Castilla JC (2001) Diversidad y biomasa de macroinvertebrados en matrices intermareales del tunicado Pyura praeputialis (Heller, 1878) en la Bahía de Antofagasta, Chile. Rev Chil Hist Nat 74:841-853 
Chapin FS, Sala O, Burke JC, Grime JP and 10 others (1998) Ecosystem consequences of changing biodiversity experimental-evidence and a research agenda for the future. Bioscience 48:45-52

Chesson PL (1986) Environmental variation and the coexistence of species. In: Diamond J, Case TJ (ed) Community ecology. Harper \& Row Publishers, New York, NY, p 240-256

Coleman FC, Williams SL (2002) Overexploiting marine ecosystem engineers: potential consequences for biodiversity. Trends Ecol Evol 17:40-44

Collins SL, Glenn SM (1991) Importance of spatial and temporal dynamics in species regional abundance and distribution. Ecology 72:654-664

Collins SL, Glenn SM (1997) Effects of organismal and distance scaling on analysis of species distribution and abundance. Ecol Appl 7:543-551

Connell JH (1961) The influence of interspecific competition and other factors on the distribution of the barnacle Chathamallus stellatus. Ecology 42:710-723

Crooks JA (1998) Habitat alteration and community-level effects of an exotic mussel, Musculita senhousia. Mar Ecol Prog Ser 162:137-152

Crooks JA (2002) Characterizing ecosystem-level consequences of biological invasions: the role of ecosystem engineers. Oikos 97:153-166

Crooks JA, Khim HS (1999) Architectural vs biological effects of a habitat altering, exotic mussel, Musculita senhousia. J Exp Mar Biol Ecol 240:53-75

Dalby JE (1997) Dimorphism in the ascidian Pyura stolonifera near Melbourne, Australia, and its evaluation through field transplant experiments. Mar Ecol Prog Ser 18: 253-271

Dayton PK (1971) Competition, disturbance, and community organization: the provision and subsequent utilization of space in a rocky intertidal community. Ecol Monogr 41: 351-389

Fairweather PG (1991) A conceptual framework for ecological studies of coastal resources: an example of a tunicate collected for bait on Australian seashores. Ocean Shore Manage 15:125-142

Gotelli N, Colwell RK (2001) Quantifying biodiversity: procedures and pitfalls in the measurement and comparison of species richness. Ecol Lett 4:379-391

Guiñez R, Castilla JC (2001) Allometric tri-dimensional model of self-thinning for a gregarious tunicate. Ecology 82: 2331-2341

Gutierrez JL, Jones CG, Strayer DL, Iribarne O (2003) Mollusks as ecosystems engineers: the role of the shell production in aquatic habitats. Oikos 101:79-90

Hacker SD, Gaines SD (1997) Some implications of direct positive interactions for community species diversity. Ecology 78:1990-2003

Hanski I (1982) Dynamics of regional distribution: the core and satellite species hypothesis. Oikos 38:210-221

Harrison S, Ross S, Lawton JH (1992) Beta diversity on geographic gradients in Britain. J Anim Ecol 61:151-158

Jones CG, Lawton JH, Shachak M (1994) Organisms as ecosystem engineers. Oikos 69:373-386

Jones CG, Lawton JH, Shachak M (1997) Positive and negative effects of organisms as physical ecosystem engineers. Ecology 78:1946-1957

Kott P (1985) The Australian ascidiacea: Part I. Phebobranchia and Stolidobranchia. Mem Qld Mus 23:328-331

Lohse DP (1993) The importance of secondary substratum in a rocky intertidal community. J Exp Mar Biol Ecol 166: $1-17$

Editorial responsibility: Otto Kinne (Editor),

Oldendorf/Luhe, Germany
Marquet PA, Navarrete SA, Castilla JC (1990) Scaling population density to body size in rocky intertidal communities. Science 250:1125-1127

McCune B, Meffort MJ (1999) PC-ORD multivariate analysis of ecological data, Version 4. MjM Software Design, Gleneden Beach, OR

Monteiro SM, Chapman MG, Underwood AJ (2002) Patches of the ascidian Pyura stolonifera (Heller, 1878): structure of habitat and associated intertidal assemblages. J Exp Mar Biol Ecol 270:171-189

Paine RT (1966) Food web complexity and species diversity. Am Nat 100:65-75

Paine RT, Levin SA (1981) Intertidal landscapes: disturbance and the dynamics of pattern. Ecol Monogr 51:145-178

Paine RT, Suchanek TH (1983) Convergence of ecological processes between independently evolved competitive dominants: a tunicate-mussel comparison. Evolution 37: 821-831

Reichmann OJ, Seabloom EW (2002) The role of pocket gophers as subterranean ecosystem engineers. Trends Ecol Evol 17:44-49

Roff JC, Taylor ME, Lauhgren J (2003) Geophysical approaches to the habitat classification, delineation and monitoring of marine habitats and their communities. Aquat Conserv Mar Freshw Ecosyst 13:77-90

SAS Institute (1996) SAS/STAT User's Guide, Release 6.12 edn. SAS Institute, Raleigh, NC

Seed R (1996) Patterns of biodiversity in the macroinvertebrate fauna associated with mussel patches on rocky shores. J Mar Biol Assoc UK 76:203-210

Sokal RR, Rohlf FJ (1991) Biometry, 2nd edn. Freeman Press, San Francisco, CA

Stachowiz JJ (2001) Mutualism, facilitation, and the structure of ecological communities. BioScience 51:235-246

Suchanek TH (1986) Mussel and their role in structuring rocky shore communities. In: Moore PG, Seed R (ed) The ecology of rocky coast. Columbia University Press, New York, NY, p 70-96

Tokeshi M, Romero L (1995) Filling a gap: dynamics of space occupancy on a mussel-dominated subtropical rocky shore. Mar Ecol Prog Ser 119:167-176

Thiel M, Ullrich N (2002) Hard rock versus soft bottom: the fauna associated with intertidal mussel beds on hard bottoms along the coast of Chile, and considerations on the functional role of mussel beds. Helgol Mar Res 56:21-30

Thompson RC, Wilson BJ, Tobin ML, Hill AS, Hawkins SJ (1996) Biologically generated habitat provision and diversity of rocky shore organisms at a hierarchy of spatial scales. J Exp Mar Biol Ecol 202:73-84

Varas M (1996) Pesca de subsistencia en el sector rocoso costero al sur de la ciudad de Antofagasta, con énfasis en el recurso 'loco' Concholepas concholepas (Bruguiere, 1789) y en la concesión costera de Minera Escondida en Punta Coloso. BSc thesis, Universidad Arturo Prat, Iquique

Vásquez J, Santelices B (1984) Comunidades de macroinvertebrados en discos de Lessonia nigrescens Bory (Phaeophyta) en Chile central. Rev Chil Hist Nat 57: 131-154

van Rensburg BJ, McGeoch MA, Matthews SL, Chown, van Jaarsveld AS (2000)Testing generalities in the shape of patch occupancy frequency distributions. Ecology 81: 3163-3177

Whittaker RH (1972) Evolution and measurement of species diversity. Taxon 21:213-251

Wright JP, Jones CG, Flecker AS (2002) An ecosystem engineer, the beaver, increases species richness at the landscape scale. Oecología 132:96-101

Submitted: August 11, 2003; Accepted: November 9, 2003

Proofs received from author(s): March 1, 2004 
Appendix 1. List of macroinvertebrate and macroalgae species. Mobile: able to change spatial location; sessile: attached to primary or secondary substrata; vagile: low mobility, but not attached. Habitat type: (1) inhabits only Pyura praeputialis matrices;

(2) only rocky substrata; (3) inhabits both

\begin{tabular}{|c|c|c|c|c|c|}
\hline Taxonomic group & Species & $\begin{array}{c}\text { Habitat } \\
\text { type }\end{array}$ & Taxonomic group & Species & $\begin{array}{l}\text { Habitat } \\
\text { type }\end{array}$ \\
\hline \multicolumn{3}{|l|}{ INVERTEBRATES } & \multicolumn{3}{|l|}{ Echinodermata } \\
\hline \multirow{4}{*}{ Nemertea: Anopla } & & & Asteroidea & Patiria chilensis & 1 \\
\hline & $\begin{array}{l}\text { Lineus atrocaeruleus } \\
\text { Unidentified Nemertea A }\end{array}$ & 1 & & Stichaster striatus & 2 \\
\hline & $\begin{array}{l}\text { Unidentified Nemertea A } \\
\text { Unidentified Nemertea B }\end{array}$ & 1 & & Heliasther helianthus & 3 \\
\hline & Unidentified Nemertea C & 2 & $\begin{array}{l}\text { Echinoidea } \\
\text { Holothuroidea }\end{array}$ & Tetrapygus niger & 3 \\
\hline \multirow{4}{*}{$\begin{array}{l}\text { Mollusca } \\
\text { Polyplacophora }\end{array}$} & & & Ophiuroieda & Ophiactis kroyeri & 1 \\
\hline & Acanthopleura echinata & 1 & Sessile & & \\
\hline & $\begin{array}{l}\text { Acanatopleura peruviana } \\
\text { Enoplochiton niger }\end{array}$ & $\begin{array}{l}1 \\
1\end{array}$ & Porifera & $\begin{array}{l}\text { Unidentified Porifera A } \\
\text { Unidentified Porifera B }\end{array}$ & $\begin{array}{l}1 \\
2\end{array}$ \\
\hline & $\begin{array}{l}\text { Enoplochiton niger } \\
\text { Chiton granosus }\end{array}$ & $\begin{array}{l}2 \\
3\end{array}$ & Cnidaria: Anthozoa & Anthothoe chilensis & 1 \\
\hline \multirow[t]{23}{*}{ Gastropoda } & Caecum chilense & 1 & & Unidentified Anthozoa & 3 \\
\hline & $\begin{array}{l}\text { Calyptraea trochirormis } \\
\text { Scurria scurra }\end{array}$ & $\begin{array}{l}3 \\
1\end{array}$ & Bryozoa: Gymnolaemata & Beania maqellanica & 1 \\
\hline & Scurria zebrina & 1 & 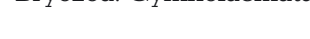 & Bugula flabellata & 3 \\
\hline & $\begin{array}{l}\text { Concholepas concholepas } \\
\text { Crepidula dilatata }\end{array}$ & $\begin{array}{l}1 \\
1\end{array}$ & Mollusca: Bivalvia & Chama pellucyda & 1 \\
\hline & Eatoniella latina & 1 & & Brachidontes granulata & 3 \\
\hline & Fissurella cumingi & 1 & & Perumytilus purpuratus & 3 \\
\hline & Fissurella limbata & 1 & & semimytilus algosus & \\
\hline & Fissurella maxima & 1 & Annelida: Polychaeta & Unidentified Spirorbidae A & 1 \\
\hline & Liotia cancellata & 1 & & Phragmatopoma moerchi & 1 \\
\hline & Mitrella unifasciata & 1 & Arthropoda & & \\
\hline & Prisogaster niger & 1 & Crustacea: Cirripedia & Verruca laevigata & 1 \\
\hline & $\begin{array}{l}\text { Tegula atra } \\
\text { Thais haemostoma }\end{array}$ & 1 & & Austramegabalanus psittacus & $S \quad 2$ \\
\hline & $\begin{array}{l}\text { I hals naemostoma } \\
\text { Trimusculus peruvianus }\end{array}$ & 1 & & Balanus flosculus & 2 \\
\hline & Collisela orbignyi & 2 & & $\begin{array}{l}\text { Balanus laevis } \\
\text { Jehlius cirratus }\end{array}$ & $\begin{array}{l}1 \\
2\end{array}$ \\
\hline & Collisela plana & 2 & & Notochthamalus scabrosus & 2 \\
\hline & $\begin{array}{l}\text { Nodilittorina araucana } \\
\text { Nodilittorina peruviana }\end{array}$ & $\begin{array}{l}2 \\
2\end{array}$ & Insecta & $\begin{array}{l}\text { Unidentified Chironomidae } \\
\text { (larvae) }\end{array}$ & 3 \\
\hline & $\begin{array}{l}\text { Scurria böhmita } \\
\text { Scurria viridula }\end{array}$ & $\begin{array}{l}2 \\
2\end{array}$ & Chordata: Ascidiacea & Molgula ficus & 1 \\
\hline & Scurria parasitica & 3 & & Unidentified colonial ascidian & n 2 \\
\hline & Scurria variabilis & 3 & & Pyura chilensis & 2 \\
\hline & Scurria ceciliana & 3 & Vagile & & \\
\hline & Fissurella crassa & 3 & Mollusca & & \\
\hline & Scurria araucana & 3 & Gastropoda & Iselica chilensis & 1 \\
\hline & Siphonaria lessoni & 3 & Bivalvia & Carditella tegulata & 1 \\
\hline \multirow[t]{17}{*}{ Annelida: Polychaeta } & Cirratulus sp. & 1 & & Entodesma cuneata & 1 \\
\hline & Cirrifornia sp. & 1 & & Lasaea petitiana & 1 \\
\hline & Dalhousiella sp. & 1 & & Mysella sp. & 1 \\
\hline & Halosydna sp. & 1 & & Nucula interflucta & 1 \\
\hline & Hemipodus sp. & 1 & & Protothaca thaca & 1 \\
\hline & Hydroides chilensis & 1 & & Nucula pisum & 2 \\
\hline & Lumbrineris sp. & 1 & ALGAF & & \\
\hline & $\begin{array}{l}\text { Marphysa sp. } \\
\text { Naineris sp }\end{array}$ & 1 & $\begin{array}{l}\text { ALGAE } \\
\text { Chlorophyta }\end{array}$ & Bryopsis peruviana & \\
\hline & Nereis callaona & 1 & Cnloropnyta & Chaetomorpha linum & 1 \\
\hline & $\begin{array}{l}\text { NereIs Calldond } \\
\text { Perinereis falklandica }\end{array}$ & 1 & & Chaetomorpha linum & 1 \\
\hline & Pherusa sp. & 1 & & $\begin{array}{l}\text { Eladophora sp. } \\
\text { Clampressd }\end{array}$ & $\frac{1}{2}$ \\
\hline & Unidentified Syllidae A & 1 & & Ulva sp. & 2 \\
\hline & Typosyllis magdalena & 1 & & Chaetomorpha aerea & 3 \\
\hline & Typosyllis sp. & 1 & & Ulva rigida & 3 \\
\hline & Pseudonereis gallapagensis & 3 & Rhodophyta & Ceramiun rubrum & 1 \\
\hline & Nereis grubei & 3 & & Gymnogongrus furcellatus & 2 \\
\hline & \multicolumn{2}{|c|}{ Arthropoda: Crustacea } & & Hypnea spicifera & 2 \\
\hline \multirow[t]{13}{*}{ Decapoda } & Betaeus emarginatus & 1 & & Rhodhymenia skottsbergii & 2 \\
\hline & Acanthonyx petiveri & 1 & & Rhodoglossum denticulatum & 2 \\
\hline & Pilumnoides perlatus & 1 & & Centroceras clauvulatum & 3 \\
\hline & Gaudichaudia gaudichaudi & 1 & & Chondrus canaliculatus & 3 \\
\hline & Pagurus edwarsii & 1 & & Corallina oficinallis & 3 \\
\hline & Pagurus villosus & 1 & & Gelidium chilensis & 3 \\
\hline & Paraxanthus barbiger & 1 & & Hildenbrandia lecanellieri & 3 \\
\hline & Petrolisthes granulosus & 1 & & Lithothamnion sp. & 3 \\
\hline & Petrolisthes violaceus & 1 & & Polysiphonia sp. & 3 \\
\hline & Pisoides edwarsi & 1 & & Porphyra columbina & 3 \\
\hline & Synalpheus spinifrons & 1 & Phaeophyta & CoÎpomenia phaeodactyla & 1 \\
\hline & Acanthocyclus gayi & 3 & & Dyctiota dichotoma & 1 \\
\hline & Allopetrolisthes angulosus & 3 & & Petalonia fascia & 1 \\
\hline \multirow[t]{6}{*}{ Amphipoda } & Hyale rubra & 1 & & Glossophora kunthii & 2 \\
\hline & Elasmopus chilensis & 1 & & Giffordia mitchelliae & 2 \\
\hline & Jassa sp. & 1 & & Ralfsia pacifica & 2 \\
\hline & Aora typica & 1 & & Lessonia nigrescens & 2 \\
\hline & Hyale media & 3 & & Endarachne binghamiae & 3 \\
\hline & Hyale grandicormis & 3 & & Colpomenia sinuosa & $\begin{array}{l}3 \\
2\end{array}$ \\
\hline \multirow{2}{*}{ Isopoda } & Jaeropsis sp. & 1 & & Halopteris hordacea & 3 \\
\hline & Dynamenella sp. & 3 & Cyanophyta & Nostoc $\mathrm{s}$ & \\
\hline Tanaidacea & Unidentified Tanaidacea A & 1 & & Lyngbia confervoides & 2 \\
\hline
\end{tabular}

